\title{
Seasonality in the Australian Stock Market
}

\author{
$\mathrm{Ha} \mathrm{Vu}^{1} \&$ Sean Turnell ${ }^{1}$ \\ ${ }^{1}$ Department of Economics, Macquarie Business School, Macquarie University, Sydney, Australia \\ Correspondence: $\mathrm{Ha} \mathrm{Vu}$, Department of Economics, Macquarie Business School, Macquarie University, Sydney, \\ Australia.
}

Received: July 17, 2019

Accepted: August 6, $2019 \quad$ Available online: August 13, 2019

doi:10.11114/aef.v6i5.4445

URL: https://doi.org/10.11114/aef.v6i5.4445

\begin{abstract}
This paper examines the presence of day-of-the-week and month-of-the-year effects in the Australian stock market over the past several decades, and investigates whether long-standing anomalies persist following the 1987 stock market crash, and the 2008 global financial crisis. We find that before the 1987 crash the Australian stock market recorded lowest returns on Tuesday and highest returns on Thursdays. However, these daily phenomena seemed to vanish in the decades since, suggesting that Australian daily share prices are more likely to move randomly. In contrast, monthly seasonality is still in place with negative returns recorded in May and June, and high returns in July, December, and April. Seasonality and predictability in Australian equity prices, though reduced, are thus seemingly not dead just yet.
\end{abstract}

Keywords: stock returns, anomalies, Australian stocks

\section{Introduction}

A traditional assumption in economics and finance was that consumers, individuals, firms, investors, and other economic agents behave more or less rationally. For stock markets, this meant that decisions to buy or sell shares in a firm were seen to depend on fundamental matters such as product innovation, a higher-than-expected earnings report, a change in management, a tariff imposed on an industry's product, an improvement in the macro-economy, or any other changes that were likely to affect the company's prospects. In other words, famously share price changes could be depicted as random walks, and markets were regarded as efficient. The latter suggested that stock prices fully reflected all available information, and thus no abnormal returns could be made from this information. Current prices already took into account known or anticipated changes in fundamentals and other meaningful news. Stock price changes incorporated no memory, and the past history of the series could not be used to predict the future in any meaningful way.

However, every now and then market participants and investors observed anomalies in this efficiency story, and all sorts of strategies and theories developed around them in the hope of profitable gain. Amongst the most commonly identified 'anomalies' in stock prices were perceived seasonal or calendar effects. Seasonality in stock markets was seen in returns that were consistently higher on certain days of the week than on other days, or in certain months of the year than other. In other words, seasonal anomalies relied on assumptions that a certain pattern of stock behavior was formed on the basis of past stock prices. If so, one could use these patterns to predict the future movement of stock prices, suggesting that stock markets were inefficient, and stock prices did not tend to move in the manner of a random walk.

\subsection{The Prevailing Literature}

There have been numerous studies attempting to reveal seasonal effects in stock prices, most of which focus on the US, European, and the UK stock markets. The common anomalies thus identified in these include the notion that average stock return on Monday is the lowest (i.e., negative and/or smaller than on other days of the week), while the average return on Friday is the highest. French (1980), using the S\&P500 Index from 1953 to 1977, found that the average return on Monday was significantly negative and lower than the average return for any other day. Keim and Stambaugh (1984) also documented an identical Monday phenomenon for the same index dating back to 1928, and likewise abnormal high returns on Friday.

Moving forward a decade, Kamara (1997) detected a significant Monday effect for small-cap stocks between 1962 and 1993. However, for S\&P500 constituents, there appeared a weakening in the Monday seasonality, or to put it differently, the Monday anomaly in the S\&P index disappeared after April 1982 (when S\&P futures contract began trading). The 
reason for this disappearance was seen to be due to declines in transaction and information costs and the rise of institutional investors in US financial markets Fixed brokerage commissions were eliminated in 1975, thus institutional investors incurred significantly lower transaction costs for larger stock trades than for small ones. As a result, the Monday effect for larger stocks declined due to the dominance of institutional trading, while small stock returns still exhibited the Monday anomaly in which individual investors traded more frequently.

Kamara's argument was in line with Power (1992) who reported that firms in the US often released news (especially bad news) after trading hours on Friday (or even over the weekend) - ideally in order to give individual investors time to digest information and make investment decisions, but oftentimes too in the hope the negative information might be missed. Either way, individual investors hence individual investors tend to sell more stock on Monday compared to other days.

With respect to international evidence, Jaffe and Westerfield (1985), aiming at testing if the above-noted weekday seasonal effect was a world-wide phenomenon, investigated stock returns in the UK, US, Australia, Canada, and Japan throughout the period of 1973-81, and found strong evidence to support this 'traditional' Monday effect in the UK, US and Canada. For Japan and Australia, the lowest average daily returns occurred on Tuesday. This was due to the time-zone differences - in both of these countries Tuesday overlapping with Monday in North America). Similarly, Agrawal and Tandon (1994) conducted an analysis for 18 countries and found that overwhelmingly (that is, 17 out of 18), lowest returns occurred either on Monday or Tuesday. In the same ballpark were the findings of Dubois and Luvet (1996) who revealed negative returns on Tuesday for Australia and Japan, and negative returns on Monday for seven other countries in the sample during the 1969-1992 period.

With emphasis on the Australian securities market (ASX) in particular, Easton and Faff (1994) investigated day-of-the-week effects for the period of 1974-1985 and found that the returns were lowest on Tuesday, and highest on Thursday. Marrett and Worthington (2008) reported that returns from the All Ordinaries (then Australia's pre-eminent stock index) from September 1996 to November 2006, were lower on both (sic) Friday and Tuesday than on other days, suggesting no common day-of-the-week effect in the Australian market.

Meanwhile, Liu and Li (2010) focused on the top 50 listed companies on the ASX, and found that weekday anomalies were mixed across companies and industries for the period of 2001 to 2010. In great contrast to the prevailing literature, however, they noted that only three companies had statistically significant negative returns on Tuesdays, while most of materials and energy companies have higher returns on Mondays than the other days.

In terms of the month-of-the-year effect, most studies found lowest returns in December, and highest in January. Using New York Stock Exchange data, Rozeff and Kinney (1976) were the first to report that average stock index returns in January were higher than in any other month across 1904-1974. Haugen and Jorion (1996) documented the January effect over the period of 1926-1993, similarly with respect to the New York Stock Exchange. They acknowledged that, given the opportunity to earn abnormal returns, investors should have seized the moment to eliminate the identified anomaly over such a long time-frame. However, as their findings revealed, investors seemed reluctant to reap this opportunity due to agency problems, risk aversion, inertia and other obstacles, resulting in the persistence of the January effect.

Mehdian and Perry (2002) reexamined this effect for US equity markets from 1964-1998, and found that the January effect was in place until the 1987 stock market crash, but did not show up in any significant way afterward.

With regard to Australian share markets, Praetz (1973), using the share price indices from 1947 to 1968, found monthly seasonal effects in all the exchanges. In particular, each index had two peaks and two troughs in most years. The peaks were in January-February and July-August, and the troughs in March-April, and November-December. Officer (1975) and Brown, Keim, Kleidon and Marsh (1983) reached similar findings across the periods of 1958-1970, and 1958-1981 respectively. In addition, Brown et al (1983) found large stock returns in July. Gaunt et al (2000) also presented evidence to support January and July high stock returns over the years of 1974-1997. However, when extending the horizon of the studied period to 2006 (from 1974), Gray and Tutticci (2007) did not find strong evidence to support the existence of either January or July effects.

Marrett and Worthington (2011) used 12 different Australian stock indices to examine the month-of-the-year effect and found that the Small Ordinaries index (that is, smaller cap stocks) showed a significant January effect, while the All Ordinaries index displayed higher returns in April, July, and December than in other months. Worthington (2010), examining Australian stock markets from 1958 to 2005, reported negative stock returns in February and September.

Internationally, Patel (2016) examined the January effect of stock returns in a number of markets, both developed and emerging ones, from 1997 to 2014, and found that January returns were lower than other months' returns in the US as well as in other developed countries. The same phenomenon was detected in emerging stock markets but the results were not statistically significant. He noted that as this study period contained the 2008-2009 GFC, the dramatic 
gyrations of financial markets more or less everywhere almost certainly coloured outcomes, hence Patel suggested that if the data was broken down into smaller time horizons, different outcomes were highly likely.

\subsection{Accounting for Seasonal and Daily Effects}

There are two conceivable reasons that are often employed in the literature (see above) to explain for the May/June anomalies (in Australia) or December/January (in the US) - namely the tax-loss selling and the window dressing hypotheses.

The tax-loss selling hypothesis suggests that investors sell stocks at the end of financial year to realize losses which then can be used to offset capital gains in order to reduce their tax liabilities (i.e., an immediate tax gain deduction is preferred to postponement). In Australia, a capital gains tax regime was first introduced in 1985, and revised in 1999. Under it, individual investors can offset capital losses from current year capital gains, and any unapplied capital losses can be carried forward to be subtracted from future gains. The net capital gains are taxed at the taxpayer's marginal rate. For institutional investors and share traders, capital gains are treated as ordinary income from realized losses can be deducted, and they pay tax at normal tax rates. Due to this feature of tax-loss deduction, either from ordinary income or capital gains, both institutional and individual investors benefit from selling losing stocks at the end of the financial year to minimize their tax payments.

The 'window-dressing' hypothesis is applicable to institutional investors, and it postulates that managers of investment funds and insurance companies, for example, might need to improve their performance by selling poorly performing stocks before the financial year end so that these losers don't show up in the portfolio, which in turn may affect managers' bonuses. The justification for this is that mutual fund managers behave in a manner consistent with the belief that a better-looking portfolio will attract additional cash investment and potential investors into the fund and raise the managers' remuneration.

With respect to day-of-the-week effects, rational explanations for persistent anomalies are rather elusive. Instead, we are thrown more or less exclusively into the realm of market and mass psychology, with both this present study and previous work asserting the possibility of 'mood' effects being a determinant.

\subsection{Purpose of this Paper}

In the light of all of the above, the purpose of this paper is to reexamine the seasonal effects in the Australian stock market, using up-to-date data and taking into consideration the recent global financial crisis to see if there has been any shift in the seasonality pattern post GFC. The paper thus contributes to the empirical studies in Australia on the issue by extending the studied period up to the most recent times to cover contemporary stock market movements. The study attempts to offer some potential explanations for the existence of the anomalies found, as well as some implications for would-be investors.

In the next section we will discuss the data set and empirical models. Sections III presents the findings and discussion, followed by the conclusion.

\section{Data and Regression Approach}

In this paper we employed the daily All Ordinaries index across the period from January 1980 to January 2018 (9938 observations), and the monthly All Ordinaries index from April 1971 to January 2018 (562 observations) ${ }^{1}$. The data was obtained from DataStream. ${ }^{2}$

The return $(R)$ for each period $t$ (either daily or monthly) was calculated from the index series as follows:

$$
R_{t}=\ln \left(P_{t} / P_{t-1}\right) \times 100
$$

in which $P_{t}$ and $P_{t-1}$ were the share price index at the end of period $t$ and $t-1$.

The summary statistics for daily returns for each category were presented in Table 1 below.

\footnotetext{
${ }^{1}$ We did not have the daily share price data for the period from 1971 to 1979.

${ }^{2}$ A global financial and economic data platform owned by leading media/financial data firm, Thomson Reuters.
} 
Table 1. Summary statistics for daily and monthly stock returns (in percentage points)

\begin{tabular}{|l|c|c|c|c|c|}
\hline & $\begin{array}{c}\text { Number of } \\
\text { observations }\end{array}$ & Mean & $\begin{array}{c}\text { Std. } \\
\text { Dev. }\end{array}$ & Skewness & Kurtosis \\
\hline Daily 1/1980 - 1/2018 & $\mathbf{9 9 3 8}$ & $\mathbf{0 . 0 2 5 4}$ & $\mathbf{0 . 9 6}$ & $\mathbf{- 3 . 2 1}$ & $\mathbf{8 5 . 7 6}$ \\
\hline Monday & 1987 & 0.0087 & 0.98 & -0.57 & 7.57 \\
\hline Tuesday & 1987 & -0.0243 & 1.11 & -9.01 & 225.11 \\
\hline Wednesday & 1987 & 0.0476 & 0.90 & -0.10 & 3.90 \\
\hline Thursday & 1987 & 0.0592 & 0.92 & -0.80 & 6.64 \\
\hline Friday & 1987 & 0.0358 & 0.88 & -0.85 & 9.49 \\
\hline Monthly 4/1971 - 1/2018 & $\mathbf{5 6 2}$ & $\mathbf{0 . 5 2 1 4}$ & $\mathbf{5 . 2 3}$ & $\mathbf{- 1 . 5 7}$ & $\mathbf{1 7 . 3 1}$ \\
\hline Jan & 47 & 1.8435 & 5.43 & 1.12 & 6.22 \\
\hline Feb & 46 & 0.7847 & 4.64 & 0.62 & 4.89 \\
\hline Mar & 46 & 1.0370 & 4.71 & 0.08 & 3.64 \\
\hline Apr & 47 & 2.3316 & 3.87 & 0.64 & 6.69 \\
\hline May & 47 & -0.6213 & 4.25 & -0.58 & 3.94 \\
\hline Jun & 47 & -0.4373 & 4.38 & -0.77 & 4.58 \\
\hline Jul & 47 & 1.3562 & 4.65 & 0.01 & 3.26 \\
\hline Aug & 47 & 0.5618 & 5.07 & -0.64 & 3.99 \\
\hline Sep & 47 & -0.3861 & 4.85 & 0.08 & 2.57 \\
\hline Oct & 47 & -1.0279 & 9.65 & -2.87 & 13.63 \\
\hline Nov & 47 & 0.3204 & 4.70 & 0.62 & 4.29 \\
\hline Dec & 47 & 0.5107 & 3.29 & -0.71 & 3.80 \\
\hline
\end{tabular}

As shown in the above table, the mean return on Tuesday was the smallest, while Thursday's was the highest, followed by Wednesday and Friday. ${ }^{3}$ This suggested that the Tuesday and Thursday effects might indeed prevail in Australian stock markets. The volatility of returns measured by standard deviations were highest on Tuesday, and lowest on Friday.

With respect to the monthly data, it was quite interesting to see that April showed the highest monthly returns, followed by January and July. On the other hand, negative returns in May and June seemed to fit the narrative of the tax-loss selling hypothesis in the months before the end of Australian financial year (which starts on July $1^{\text {st }}$ and ends on June $\left.30^{\text {th }}\right)$. Returns looked less volatile in December, and most gyrated in October.

To detect weekday effects we ran the following regression:

$$
R_{t}=\alpha_{0}+\beta_{i} D_{i}+\varepsilon_{t}(i=1: 5 ; \text { representing Monday through Friday) }
$$

where $R_{t}$ was the daily return; $D_{1}$ was a dummy variable and equal 1 for Monday, and 0 for other days; $D_{2}-D_{5}$ were dummy variables for Tuesday - Friday. The average day $i$ return was measured by $\beta_{i}$ and the average return for other days was measured by $\alpha_{0}$. The difference in returns between day $i$ and the other four days was equal to $\beta_{i}$ minus $\alpha_{0}$.

In the context of Australia and in line with the previous studies, it was expected that $\beta_{2}$ for Tuesday would be negative and lowest, and $\beta_{4}$ for Thursday would be positive and highest.

Similarly, to test if the returns of a certain month were significantly and statistically higher or lower than the average returns of all other months, we ran the following regression:

\footnotetext{
${ }^{3}$ Note though that the high returns on Wednesdays might not offer any implication, but rather may be due to a technical reason. Because of a reduction in the stock index on Tuesdays, the returns on Wednesdays (calculated as the percentage change in stock index between Tuesday and Wednesday) would be quite large, for no other reasons beyond simply in juxtaposition to the previous day.
} 


$$
R_{t}=\alpha_{0}+\alpha_{j} M_{j}+\varepsilon_{t}
$$

in which $R_{t}$ was the monthly return; $M_{j}$ was a dummy variable receiving the value of 1 for month $j$, and zero otherwise. The dummy coefficients $\alpha_{j}$ showed the average monthly returns for each of the months from January ( $j=1$ ) to December $(j=12)$. If the January effect - the commonly detected effect in the literature - held, the estimated coefficient $\alpha_{1}$ would be positive and had the highest value.

In this equation, $\alpha_{0}$ represented the average returns for the other 11 months, and $\alpha_{j}$ represented the return of month $j$. The difference between month $\mathrm{j}$ returns and the mean returns of the others was calculated by $\left(\alpha_{j}-\alpha_{0}\right)$.

In case the January pattern holds, $\alpha_{1}$ would be significantly positive. For the Australian stock market, one could expect $\alpha_{7}$ (for July) to be positive as the financial year in Australia runs from the $1^{\text {st }}$ of July to the $30^{\text {th }}$ of June. Similarly, in accordance with the hypothesis of tax-loss selling we could expect the estimated coefficient for June to be negative.

Furthermore, there might be a possibility that seasonality is in a continual state of flux, rather than fixed over time. Accordingly, we were interested in testing how seasonal effects might vary over the studied period. Since our sample period covered two major stock market crashes, in October 1987 and in September 2008, we thus divided the sample period into three sub-periods: pre-1987-crash (from the start of the studied period to October 1987), between the two crises (from Sep 1987 to Sep 2008), and post-crisis (from October 2008 to January 2018).

\section{Findings and Discussion}

To make sure the regression analysis is appropriate, we check the stationarity of the return series using the Augmented-Dickey Fuller test, and the null hypothesis of a unit root is rejected at $1 \%$ level of significance. In addition, we also use the Breusch-Godfrey test for autocorrelation and the White's test of heteroskedasticity in the residuals. As a result, the null hypothesis of no serial correlation is rejected for all estimated models, while the null hypothesis of heteroskedasticity is not rejected, implying that the residuals are highly correlated and the least square residuals are different from zero. To correct these problems and to improve the credibility of the regression results, we employ robust regressions to compute heteroskedasticity and autocorrelation-consistent (HAC) standard errors developed by Newey and West (thus often referred to as Newey-West standard errors).

Table 2. Estimated coefficients and p-value of day-of-the-week models

$\begin{array}{cccc}2 \text { Jan } 1980- & \text { 2 Jan } 1980- & \text { 20 Oct 1987- } & \text { 16 Sep 2008- } \\ \text { 31 Jan 2018 } & \text { 19 Oct } 1987 & 15 \text { Sep 2008 } & \text { 31 Jan 2018 } \\ \text { (whole sample }) & (\text { Pre-1987 crash }) & (\text { Post-1987crash \& } & \text { (PostGFC) } \\ & & \text { Pre-GFC }) & \end{array}$

(1)

(2)

(3)

(4)

\begin{tabular}{|c|c|c|c|c|}
\hline Monday & $-0.021(0.395)$ & $-0.025(0.642)$ & $-0.016(0.623)$ & $-0.028(0.582)$ \\
\hline Constant & $0.029(0.006 * * *)$ & $0.075\left(0.0^{* * *}\right)$ & $0.019(0.185)$ & $0.015(0.518)$ \\
\hline Tuesday & $-0.062(0.022 * *)$ & $-0.224(0.0 * *)$ & $-0.035(0.366)$ & $0.013(0.810)$ \\
\hline Constant & $0.038(0.000 * * *)$ & $0.114(0.0 * * *)$ & $0.023\left(0.085^{*}\right)$ & $0.007(0.769)$ \\
\hline Wednesday & $0.028(0.228)$ & $0.006(0.898)$ & $0.032(0.306)$ & $0.037(0.451)$ \\
\hline Constant & $0.019(0.071 *)$ & $0.069(0.002 * * *)$ & $0.010(0.511)$ & $0.002(0.934)$ \\
\hline Thursday & $0.042(0.070 *)$ & $0.106(0.030 * *)$ & $0.028(0.335)$ & $0.020(0.712)$ \\
\hline Constant & $0.017(0.122)$ & $0.049(0.027 * *)$ & $0.010(0.489)$ & $0.005(0.816)$ \\
\hline Friday & $0.013(0.565)$ & $0.136(0.003 * * *)$ & $-0.009(0.739)$ & $-0.041(0.421)$ \\
\hline Constant & $0.022(0.039 * *)$ & $0.042(0.058 *)$ & $0.018(0.235)$ & $0.018(0.451)$ \\
\hline
\end{tabular}

Note: ***1\% significant level; $* * 5 \%$ significant level; $* 10 \%$ significant level

Table 2 presents the regression results obtained from running equation (2) for daily stock returns for the whole period as well as for each sub-period. As shown in column (1) the estimated coefficients for Tuesday and Thursday are statistically significant at the level of $5 \%$ and $10 \%$ correspondingly, indicating that Tuesday and Thursday effects do exist throughout the entire studied period. These weekday effects are in line with the previous empirical studies in Australia (Worthington, 2010). 
More specifically, the average Tuesday returns are negative and about $0.1 \%$ (which is equal to $-0.062-0.038$ ) lower than the average returns of the other days. Given the 'traditional' Monday effect existed in the US stock markets, and that the Australian share market is highly affected by movements in the US, the existence of the Tuesday effect in Australia might be expected. This effect represents the lagged influence of the US market (i.e., as noted earlier, if the Monday effect takes place in US stock markets, it would become a Tuesday effect in Australia due to different time zones). For instance (as but one example), following a large stock market rout (above 2\%) in the US market on Monday February 5, 2018 (the US market closed at 8am Sydney time), the S\&P/ASX200 index (which opens 2 hours later) on Tuesday February 6 fell by about 3.5\%. ${ }^{4}$ Another possible explanation for the Tuesday seasonal effect is that most of the public holidays in Australia fall on Mondays (such as Easter Monday, Queens Birthday, Labour Day), therefore the supposed reduction in Monday stock returns is shifted to Tuesday.

The findings also reveal a Thursday anomaly in which the day returns are positive and about $0.025 \%$ higher than the mean returns of the other four days. The high stock returns on Thursday is difficult to explain. We posit that it might be due to culture and custom. In Australia Thursday has been the extended-hours shopping day - a day of the week when people often left work early to enjoy social interactions and, possibly, felt somewhat lighter of heart than other days in the week. And thus people were perhaps more bullish about share prices.

From these Tuesday and Thursday return irregularities, one might suggest that traders and investors can make arbitrage profits by purchasing shares on Tuesday and then selling their holdings on Thursday. However, given the reasonably long time-horizon of the studied period, within which there have been a number of boom and bust cycles, one should not expect these anomalies to hold.

Column (2) of Table 2 shows the regression results for the period up until before so-called Black Monday, on 19 October 1987. ${ }^{5}$ It appeared that the Australian stock market was clearly characterized by Tuesday and Thursday effects during this period, with the average Tuesday returns being $0.34 \%$ lower and the Thursday returns being $0.057 \%$ higher than the mean returns of other days. It is worth noting that these differences are much more significant than the ones we discussed earlier for the entire period, strengthening the existences of these weekday effects.

With respect to the period between the two crises (post 1987 crash and pre GFC), although the average Tuesday return remain lower than the average returns for other days, the difference is not significant even at the level of $10 \%$. Likewise, the notion of higher Thursday returns relative to other days' returns is not supported by statistical evidence. Hence the seasonal effects observed in the pre-crash period were diluted. The disappearance of these effects could be explained by transaction and information costs. In the mid-1980s financial deregulation took place in Australia (as well as elsewhere in developed countries), leading to increase competition and lowering brokerage and other fees on the buying and selling of shares. This period was also characterized by increased computerization and internet access that reduced the cost of collecting and analyzing information. As a result of lower transaction and information costs, any profitable arbitrage opportunity became short live, and daily abnormal returns were eliminated.

In the period post-GFC, there seem to have been some shifts in the weekday pattern of returns. As can be seen in column (4), the average Tuesday return has become positive, and the average return on Friday has become negative, while the highest daily return occurs on Wednesdays. Having said that though, these differences are not significant, even at the $10 \%$ level.

In short, our findings support the presence of 'common' day-of-the-week patterns in Australia in the period before the 1987 stock market crash. However, these patterns have diminished since. This is quite conceivable in the sense that market participants, as previously noted would quickly exploit the anomalies by taking a long position on the day of market sell-off (i.e. on Tuesdays) and closing down the position or taking a short position on the day with the highest returns. Overtime, as investors keep chasing these opportunities, share prices on Tuesday would go up, and share prices on Thursday would go down until any significant difference in daily returns ultimately disappeared.

Taking a closer look at the gyrations in stock markets one would find that stock prices are very sensitive to news, not just fundamental economic news such as labor data, consumption indices or trade policy changes and the like, but also political news and events such as the movements of key personnel in and out of the US Administration (in recent times,

4 In fact, Loh (2013) showed that the Australian stock market has a high correlation with the US stock markets with the coefficient of 0.69 .

5 The Dow Jones Industrial index fell by almost $23 \%$ in a single day. In Australia it was referred to as the Black Tuesday due to the different time zones, and all Ordinaries index declined by about $25 \%$. We did check the robustness of this outlier and found no significant difference in terms of estimated results from excluding the Black Tuesday from the sample. 
the fast-revolving Trump White House), or the likelihood of meetings over global trouble spots such as North Korea. Of course, as stock markets around the world are now more interconnected (reflecting the economies and societies they serve), one might expect that such international events impact upon investor sentiment, and influence share prices in ways similar to more orthodox fundamentals such as profit or dividend announcements.

As Worthington (2010) suggests, there are a number of possible explanations for this disappearance of the weekday seasonality effects in Australia. Firstly, the growth in derivative markets reduces the volatility in stock prices as investors and firms use derivatives to hedge against (or exploit) strong movements. Secondly, the liberalization of the domestic capital market allows foreign investors to buy Australian securities, as well as foreign companies to list on the Australian stock market, thus diversifying the investor pool as well as listed stocks. Thirdly, there has been a significant decline in transaction costs such as brokerage fees and taxation charges (e.g, dividend imputation), making the stock market more accessible to 'mum-and-dad' investors. Finally, and apropos of the Thursday effect noted, the liberalization of shopping hours in Australia largely robbed that day of its hitherto social cache.

Turning to the models exploring month-of-the-year anomalies, a number of interesting results can be drawn from Table 3 below. If we consider the entire range of data from April 1971 to January 2018, the outcomes in column (1) reveal that the returns in April are the highest followed by January, while May records the lowest positive returns (almost $2 \%$ lower than the average returns for other months), as well as a preponderance of negative returns. All of these findings are strongly supported by the statistical evidence.

If we take into consideration the period before the 1987 stock market crash, the results in column (2) uncover significant positive returns for January and April in relation to other months. Although the returns in May and June are negative, signifying the possible potency of the evidence of the tax-loss selling hypothesis, they are not statistically supported. Note that these findings cover the sub-period from April 1971 to September 1987, but the Capital Gains Tax was not introduced in Australia until September 1985. ${ }^{6}$ As it normally takes time for a new policy to take effect, there is no clear evidence of a sell-off in May and June in the period up to 1987.

In between the two crises, most of the parameters shown in column (3) are statistically insignificant, indicating no evidence of seasonality in the aftermath of the 1987 crash, or before the demise of Lehman Brothers and the triggering of the GFC.

However, since the GFC and until the present, some interesting anomalies seem to arise. Stock prices fall substantially in May and then a bit further in June, with the returns in May at nearly 3.6\% and June 1.96\% lower than the average returns for other months. Noteworthy is that stock holders do not seem to wait until the very last month of the financial year to sell, but rather begin to sell in May to receive a higher price for shares before they fall further in June. This practice is rational given that the May/June effect is (by now) perceived to be true, and expected among investors.

The fact that the negative returns in June are smaller than in May suggests that there might be some buying phenomenon in June, although not large enough to offset the overall selling trend. One would expect that professional and experienced traders could start purchasing in June when stock prices go down to a support level (constructed by their technical analysts). Likewise, in July, when the new financial year starts and the selling pressure disappears, as more and more investors come in to the market to build a new portfolio, prices begin to recover. Hence, it is reasonable to expect stock prices to bounce back strongly. In fact, our findings show that stock returns in July are statistically 3.3\% higher than the average returns of other months.

\footnotetext{
${ }^{6}$ According to Brown, Ferguson and Sherry (2010), before 1985, share traders such as Australian tax-paying financial institutions had to pay taxes at normal rates on all realized gains after deducting all realized losses regardless of the holding period, while share investors did not have to pay capital gains.
} 
Table 3. Estimated coefficients and p-values of month-of-the-year models

$\begin{array}{cccc}\text { April 1971- } & \text { April 1971- } & \text { Oct 1987- } & \text { Oct 2008- } \\ \text { Jan 2018 } & \text { Sep 1987 } & \text { Sep 2008 } & \text { Jan 2018 } \\ \text { (whole sample }) & (\text { Pre-1987 crash }) & (\text { Post-1987crash \& } & \text { (PostGFC) } \\ & & \text { Pre-GFC) } & \end{array}$

(1)

(2)

(3)

(4)

\begin{tabular}{|c|c|c|c|c|}
\hline January & $1.443(0.078 *)$ & $3.347(0.092 *)$ & $0.878(0.235)$ & $-0.389(0.719)$ \\
\hline Constant & $0.401\left(0.081^{*}\right)$ & $0.707(0.099 *)$ & $0.233(0.478)$ & $0.234(0.617)$ \\
\hline February & $0.287(0.689)$ & $0.102(0.948)$ & $-0.004(0.997)$ & $1.305(0.215)$ \\
\hline Constant & $0.498(0.033 * *)$ & $0.970(0.03 * *)$ & $0.306(0.346)$ & $0.094(0.839)$ \\
\hline March & $0.562(0.439)$ & $0.046(0.976)$ & $0.635(0.497)$ & $1.322(0.285)$ \\
\hline Constant & $0.475\left(0.041^{* *}\right)$ & $0.974(0.03 * *)$ & $0.253(0.435)$ & $0.315(0.446)$ \\
\hline April & $1.975(0.001 * * *)$ & $2.708(0.028 * *)$ & $1.362(0.113)$ & $1.986(0.0 * * *)$ \\
\hline Constant & $0.356(0.129)$ & $0.512(0.062 *)$ & $0.192(0.554)$ & $0.039(0.933)$ \\
\hline May & $-1.247(0.058 *)$ & $-1.471(0.210)$ & $-0.074(0.924)$ & $-3.595(0.035 * *)$ \\
\hline Constant & $0.626(0.008 * * *)$ & $1.104(0.016 * *)$ & $0.312(0.341)$ & $0.488(0.267)$ \\
\hline June & $-1.046(0.122)$ & $-1.26(0.391)$ & $-0.50(0.534)$ & $-1.957(0.073 *)$ \\
\hline Constant & $0.609(0.009 * * *)$ & $1.086(0.016 * *)$ & $0.348(0.288)$ & $0.356(0.440)$ \\
\hline July & $0.911(0.201)$ & $-0.169(0.909)$ & $0.739(0.430)$ & $3.30(0.001 * * *)$ \\
\hline Constant & $0.445\left(0.056^{*}\right)$ & $0.993(0.028 * *)$ & $0.244(0.451)$ & $-0.066(0.884)$ \\
\hline August & $0.044(0.954)$ & $-0.220(0.883)$ & $0.458(0.638)$ & $-0.464(0.792)$ \\
\hline Constant & $0.518\left(0.026^{* *}\right)$ & $0.997(0.027 * *)$ & $0.268(0.408)$ & $0.236(0.598)$ \\
\hline September & $-0.990(0.181)$ & $-0.086(0.951)$ & $-1.834(0.054 *)$ & $-0.767(0.629)$ \\
\hline Constant & $0.604(0.009 * * *)$ & $0.985(0.03 * *)$ & $0.459(0.155)$ & $0.260(0.565)$ \\
\hline October & $-1.691(0.231)$ & $-2.419(0.207)$ & $-1.982(0.418)$ & $0.150(0.959)$ \\
\hline Constant & $0.663(0.001)$ & $1.17(0.007 * * *)$ & $0.471(0.058)$ & $0.185(0.994)$ \\
\hline November & $-0.219(0.760)$ & $0.982(0.498)$ & $-0.072(0.938)$ & $-2.42(0.037 * *)$ \\
\hline Constant & $0.539(0.021 * *)$ & $0.899(0.046 * *)$ & $0.312(0.336)$ & $0.414(0.367)$ \\
\hline December & $-0.012(0.982)$ & $-1.530(0.193)$ & $0.393(0.558)$ & $1.632(0.021 * *)$ \\
\hline Constant & $0.522(0.028 * *)$ & $1.102(0.016 * *)$ & $0.273(0.407)$ & $0.053(0.911)$ \\
\hline
\end{tabular}

As the year progresses, there appears no abnormal returns from August to October. However, we detect a quite substantial sell-off phenomenon in November, and this could be due to seasonal liquidity needs for Christmas from both individual and institutional investors. Then the prices rebound in December, perhaps due to a feeling of 'good fellowship and cheer' in the lead up to Christmas, and the traditional holiday period that follows.

It is interesting to note that stock returns in April increase quite considerably in both the period before the 1987 crash as well as after the GFC. As this time of the year marks no special events, the change could be due to early portfolio rebalancing or window dressing by institutional investors at the beginning of a new quarter. Nevertheless, an entirely satisfying answer to this phenomenon remains elusive.

There are a number of implications from all of this for the would-be investors and traders. Firstly, if investors aim at holding shares within a horizon of one year, the best time to enter the Australian stock market is sometime during May or June, after which a holding strategy is suggested all the way until April to sell and realize profit. Secondly, there no longer exists a trading rule in which traders can make arbitrage profit by purchasing at the beginning of the week and selling toward the end of the week. Having said that though there might be some profitable opportunities regarding price movements of individual stocks. 


\section{Conclusion}

In this study we investigated the existence of monthly anomalies to see if the Australian equivalent of the internationally-observed 'December- January' effect prevailed in the Australian stock market (where, because of the different financial year, is thus the June-July effect). We found that it did, and that it has become more pronounced since the GFC. And, also consistent with international patterns, the common reasons behind this anomaly are tax-loss selling and window dressing at the end the financial year.

We also examined day-of-the-week effects, seeking to scrutinize whether negative returns on Monday in evidence in North America were anomalies in Australia too. Once again, taking into account different time zones and some local factors, we found that buy-on-Tuesday and sell-on-Thursday strategies might indeed have been a way to make profit before the 1987-crash occurred. But since this latter event, daily stock prices seem to follow a random walk.

\section{References}

Agrawal, A., \& Tandon, K. (1994). Anomalies or illusions? Evidence from stock markets in eighteen countries. Journal of International Money and Finance, 13(1), 83-106. https://doi.org/10.1016/0261-5606(94)90026-4

Brown, P., Keim, D. B., Kleidon, A. W., \& Marsh, T. A. (1983). Stock return seasonalities and the tax-loss selling hypothesis: analysis of the arguments and Australian evidence. Journal of Financial Economics, 12(1), 105-127. https://doi.org/10.1016/0304-405X(83)90030-2

Brown, P., Ferguson, A., \& Sherry, S. (2010). Investor behaviour in response to Australia's capital gains tax. Accounting \& Finance, 50, 783-808. https://doi:10.1111/j.1467-629X.2010.00352.x

Dubois, M., \& Louvet, P. (1996). The day-of-the-week effect: The international evidence. Journal of Banking \& Finance, 20(9), 1463-1484. https://doi.org/10.1016/0378-4266(95)00054-2

Easton, S. A., \& Faff, R. W. (1994). An investigation of the robustness of the day-of-the-week effect in Australia. Applied Financial Economics, 4(2), 99-110. https://doi.org/10.1080/758523954

French, K. R. (1980). Stock returns and the weekend effect. Journal of Financial Economics, 8(1), 55-69. https://doi.org/10.1016/0304-405X(80)90021-5

Gray, P., \& Tutticci, I. (2007). Australian stock market anomalies: A review and re-examination of the January and small firms effect. Journal of Investment Strategy, 2(2), 27-36

Gaunt, C., Gray, P., \& McIvor, J. (2000). The impact of share price on seasonality and size anomalies in Australian equity returns. Accounting and Finance, 40, 33-50.

Haugen, R., \& Jorion, P. (1996). The January Effect: Still There after All These Years. Financial Analysts Journal, 52(1), 27-31. http://www.jstor.org/stable/4479893

Jaffe, J., \& Westerfield, R. (1985). The Week-End Effect in Common Stock Returns: The International Evidence. The Journal of Finance, 40(2), 433-454. https://doi.org/10.1111/j.1540-6261.1985.tb04966.x

Kamara, A. (1997). New Evidence on the Monday Seasonal in Stock Returns. Journal of Business, 70, 63-84. http://www.jstor.org/stable/2353481

Keim, D. B., \& Stambaugh, R. F. (1984). A Further Investigation of the Weekend Effect in Stock Returns. The Journal of Finance, 39(3), 819-835. https://doi.org/10.1111/j.1540-6261.1984.tb03675.x

Loh, L. (2013). Co-movement of Asia-Pacific with European and US stock market returns: A cross-time-frequency analysis. Research in International Business and Finance, 29, 1-13. https://doi.org/10.1016/j.ribaf.2013.01.001

Liu, B., \& Li, B. (2010). Day-of-the-Week Effects: Another Evidence from Top 50 Australian Stocks. European Journal of Economics, Finance and Administrative Sciences, 24, 78-87

Marrett, G., \& Worthington, A. (2008). The Day-of-the-week Effect in the Australian Stock Market: An empirical note on the Market, Industry and Small Caps effects. International Journal of Business and Management, 3(1), 3-8. https://core.ac.uk/download/pdf/143867854.pdf

Marrett, G., \& Worthington, A. (2011). The Month-of-the-year Effect in the Australian Stock Market: A Short Technical Note on the Market, Industry and Firm Size Impacts. Australasian Accounting, Business and Finance Journal, 5(1), $117-123$.

Mehdian, S., \& Perry, M. J. (2002). Anomalies in US equity markets: a re-examination of the January effect. Applied Financial Economics, 12(2), 141-145. https://doi.org/10.1080/09603100110088067

Officer, R. R. (1975). Seasonality in Australian capital markets: Market efficiency and empirical issues. Journal of Financial Economics, 2, 29-51. https://doi.org/10.1016/0304-405X(75)90022-7 
Patel, J. B. (2016). The January Effect Anomaly Reexamined In Stock Returns. Journal of Applied Business Research, 32(1), 317-324. https://doi.org/10.19030/jabr.v32i1.9540

Power, W. (1992, December 3). Peter Lynch's advice to small investors: Don't become fixated on mutual funds. Wall Street Journal, C1-C2.

Praetz, P. D. (1973). A Spectral Analysis of Australian share prices. Australian Economic Papers, 12, 70-78. https://doi.org/10.1111/j.1467-8454.1973.tb00296.x

Rozeff, M. S., \& Kenney, W. R. (1976). Capital market seasonality: the case of stock returns. Journal of Financial Economics, 3, 379-402. https://doi.org/10.1016/0304-405X(76)90028-3

Worthington, A. C. (2010). The decline of calendar seasonality in the Australian stock exchange, 1958-2005. Annals of Finance, 6(3), 421-433. https://doi.org/10.1007/s10436-008-0111-9

\section{Copyrights}

Copyright for this article is retained by the author(s), with first publication rights granted to the journal.

This is an open-access article distributed under the terms and conditions of the Creative Commons Attribution license which permits unrestricted use, distribution, and reproduction in any medium, provided the original work is properly cited. 